\title{
Clover Hill Dairies: Balancing productivity and treading lightly in the centre of a rural residential development and a rainforest
}

\author{
LYNNE and MICHAEL STRONG \\ 105 Clover Hill Rd, Jamberoo NSW 2533, Australia \\ Lmnstrong_adsl@hotkey.net.au
}

Clover Hill Dairies is a progressive and highly intensive dairy farm, which currently milks 200 cows on 50 hectares three times a day on steep rainforest hinterland country. Milk production (305 day) currently averages 13000 litres and $850 \mathrm{~kg}$ of milk solids per cow making Clover Hill Dairies one of the highest production dairy farms in Australia. The stud Holstein herd is fed a predominately pasture based diet with supplementary feeding comprising $35-40 \%$ of the dietary intake.

Clover Hill Dairies aims to optimise the genetic potential of our high end genetic merit herd through close attention to pasture and soil management, biodiversity and the environment. Combining this with the application of the latest scientific principals and technology skills, we produce over 50000 litres per hectare from the 200 cows.

We recognise agriculture is no longer just about farming; it is intrinsically tied in with managing the environment and minimising the impact of human endeavours, hence the ongoing need to balance productivity and progress with minimal environmental footprint.

Clover Hill Dairies strives to adopt a holistic decision making process to ensure higher quality of life, financial stability including managing and reducing debt, consistent profitability, and the confidence of knowing that our decisions are improving the environment and the community we live in.

The key factors are herd genetics; best practice herd and farm management; the management and operational team; and interaction with the environment and the community.

\section{Herd genetics}

The farm was originally established with a pure Illawarra herd. Towards the end of the 1990s, deregulation forced us to look at more profitable alternatives. We replaced our Illawarra herd with a Holstein herd and have selected and grown large framed stud Holsteins weighing upwards of $650-700 \mathrm{~kg}$. Operating as Mandelyn and Tangalla Holsteins, we have had many show successes including Junior Champion International Dairy Week in 2000, Supreme Best Uddered Cow and HM Intermediate Champion in 2004 and All Australian $3 \mathrm{yr}$ old cow in 2005. AI is the preferred method of insemination with the majority of our semen sourced from North America.

We select bulls to correctively mate to ensure our cows are fit for purpose on the following criteria:

1. Type

2. Udders

3. Feet and legs

4. Components (especially $+\%$ fat components) Protein has been traditionally good.

We currently hold the majority of NSW class production records and two cows in our herd hold Australian production records for litres per 305 days and milk solids per 305 days. We have a number of cows that have doubled their liveweight in milk solids production. The herd averages three to four lactations.

\section{Farm management and economic performance}

We are focused on a holistic farming model that acknowledges the interdependence that coexists with all aspects of farming management. To get the most from any input, we recognise all the other inputs must be in order.

We are an intensive grazing herd operation and view concentrate feeding in the dairy as an opportunity. Average concentrate intake is around 3.6 tonnes per head and we target pasture intake of between 5 and 6 tonnes of dry matter per head. Our pasture yields per hectare are between 18 and 20 tonnes of dry matter harvested. We aim to offer at least $30 \mathrm{~kg}$ of dry matter per head daily to our cows. Our high production cows have opened our eyes to how much cows can eat and the returns on offer from allowing them unrestricted access to pasture where possible. Some of our cows peaking at over 80 litres per day must be consuming in excess of $40 \mathrm{~kg}$ of dry matter and it is only when you focus on feeding cows that you see true genetic potential expressed.

Our pasture system is based on kikuyu oversown annually with ryegrass. Our rainfall is year-round with peaks in late summer/autumn and late-spring. We strive for very high soil fertility through a combination of both manure based and inorganic fertilisers. We soil test annually and run a nutrient budget aiming to improve long term problem paddocks, capturing nutrient excesses and fertilising to requirement.

The vigorous nature of the kikuyu forces us to oversow every year. This commences in late March. We broadcast $40-50 \mathrm{~kg} / \mathrm{ha}$ of long season tetraploid ryegrass (Feast II). This is done prior to grazing, allowing cows to walk the seed into the paddock. It is further grazed by dry 
cows and then either topped if residuals are high or left to germinate and establish. While the cost of this exercise is high, we look at the cost of the feed rather than the seed and our excellent winter and spring ryegrass pastures allow our herd to peak at over 40 litres through the period.

The herd is milked three times a day. This has lead to a $20-25 \%$ improvement in productivity and has highlighted the benefit of milking high genetic merit cows. We worked with our consultant before embarking on this process and reviewed our system and looked at our key weaknesses. The renovation of our dairy in 2002 allowed us to optimise milking efficiency and make three times daily milking a reality.

For those considering a change to $3 \mathrm{X}$ we suggest the following checklist:

- Herd should already be producing at a moderate to high level

- Herds should have a good body condition score

- Milking time should not exceed 2 hours per milking

- Management should be committed to fully feeding the herd

- Tracks and laneways should be excellent and general cow flow should be rapid.

- A wet weather contingency should be developed

- Distance to grazed paddocks should not exceed $1 \mathrm{~km}$

- Milking equipment and milk harvest management should be of a very high standard

- All farm team members must be committed to change

- Consider temporary $3 X$ in early lactation in seasonal herds during the period after calving.

The farm is steep (and very slippery in the wet) and we continually monitor and upgrade the laneways when necessary. We pay close attention to providing shade in the middle of the day, not walking the cows too far in the heat, avoiding acidosis and addressing all foot issues as soon as they arise.

Heifers and dry cows are raised off farm on a lease block $5 \mathrm{~km}$ away. We focus on pasture management on the lease block and also supplementary feed the heifers when necessary, aiming to exceed $580 \mathrm{~kg}$ at calving at 22-26 months of age.

\section{Environmental Stewardship Background}

Clover Hill Dairies is a dairy centric rural residential subdivision. There are 12 Torrens title blocks ranging from 40 hectares to 0.4 hectare within the dairy environs. The road access to all blocks runs through the centre of the property. The dairy's "right to farm" is protected by a series of covenants and caveats.

Clover Hill Dairies community area covers diverse and important environmental zones. It includes the headwaters of Fountaindale Creek which flows directly into the Minnamurra River and wetlands area via the historic Fountaindale Dam. This dam is located within the community area and flowing into it is a series of small pristine mountain streams. These streams bisect significant areas of remnant rainforest, much of which is unspoilt, is zoned High Conservation and supports a wide and thriving variety of native birds, animals and reptiles.

It also includes a rural residential area which has been sensitively handled to provide separation and seclusion, with minimal impacts on both the natural environment and dairying farmland for which the Kiama region is renowned. This could well be a role model for future farm subdivisions, to preserve our economically endangered agricultural industry.

The topography is generally steep and is in a high rainfall area. In the last decade which has been drier than previous periods, annual rainfall has been above 1500 $\mathrm{mm}$. The rainfall pattern, whilst typically spread throughout the year, is characterised by periods of intense and heavy downpours in late summer/autumn and late spring, which turn the mountain streams into raging torrents and create significant runoff problems.

Other environmental issues that if not tackled will eventually lead to severe degradation include:

- Native birds and animals threatened by feral cats and foxes.

- Invasive weeds.

- Surface effluent, particularly in high runoff periods, where formed cow tracks to the milking shed coincide with residential roads and cross streams.

The residents of the rural subdivision and the dairy farm have formed an incorporated body with the primary objective for the dairy farm to be a long term thriving commercial enterprise, maintaining the present standards of pasture care and maintenance and visual pleasure. To facilitate this the subdivision's 12 rural residential landholders work actively in partnership with the dairy farm to manage, protect and enhance our unique community environment, rainforest and waterways.

\section{Environmental on-ground works}

Australian farmers are able to access community good funding for environmental on-ground works if they are proposing activities with a very high public benefit. The aim of the funding is to provide the opportunity and means to undertake small on-ground projects tackling important local problems; and to provide a mechanism through which farmers and community groups can move towards effective engagement in broader regional approaches to natural resource management.

Environmental grants ensure that farming's ecological footprint is minimised not only on private properties but, equally importantly, reduces nutrient loading in the wider catchment estuary/mangrove systems and for 
landholders downstream who use water for livestock and domestic use. Clover Hill Dairies has invested considerable time and effort into seeking these grants and our efforts have rewarded both the environment and our farm productivity.

Clover Hill Dairies has accessed over $\$ 100,000$ for environmental on-ground works in the last 2 years including Natural Hertiage Trust - Envirofund. This money has been used to provide alternate water sources and access routes for dairy cattle, farm machinery and fertiliser trucks on the farm to protect creeks and riparian vegetation. This project will help complete a 6 year farm plan that aims to eliminate casual stock access from all farm watercourses, minimise essential stream crossings for stock, machinery and vehicles and provide off stream stock watering points and shade. This will help reduce nutrients, sediment and faecal coliforms entering the creek and improve downstream water quality.

Improving our effluent system has been a high priority since we commenced three times daily milking. The current system, only installed 3 years ago, was not coping with a $30 \%$ increase (we use $20 \%$ less water for the night time hose down) and major rainfall events storm water runoff. Funding from the 2006 Community Waterwise Grant is helping us install a proven recycling system to enable dairy effluent to be utilised as fertiliser and filtered through fenced and enhanced riparian buffer zones. The project aims to augment and re-establish native vegetation within the riparian zone to act as nutrient buffering zones; as well as multiplying an increased community awareness of environmental works which are occurring on local dairy farmers and boosting their "green" image.

Involvement in the environmental grant process and delivery enhances the farm team's holistic perspective by giving us a greater understanding of the way our farm works as an ecological unit and the processes that support this as well as increasing our communication and natural resource management skills.

This funding has enabled our farm to reach equilibrium between the environmental and the economic realities of farming. Equally, we get pleasure from the returns of growing native windbreaks, fencing off, revegetation and rehabilitation of waterways to attract more native bird and wildlife back to the farm. We recognise our environmental expertise is not inherent and if you are going to do something you may as well optimise the benefit. Hence we outsource this knowledge by tapping into all the know-how in our area.

Farm and herd management strategies for minimising greenhouse gas emissions (GHGE)

Herd methane output is minimised by the following strategies:
- Feeding livestock highly digestible feed such as grain based concentrates and high-quality pasture (ryegrass and high ME kikuyu) which increases milk production per cow and hence reduces methane emissions per unit of milk production overall.

- Rumen modifiers Rumensin and Virginiamycin are added to concentrates which theoretically has a positive effect on GHGE reduction.

- Using protected fats in the diet allows us to increase energy intake by a method that does not involve fermentation.

- We have also planted over 2000 native trees, shrubs and grasses in the past 5 years.

Nitrate output is minimised by:

- Judicious fertiliser application using a budget formulated by our consultant based on regular soil tests.

- Using organic fertilisers (poultry manure) where possible and following best practice application rate and timing procedures.

- Zero tillage and application of fertilisers to paddocks with good residuals to minimise runoff risk.

- Ensuring "sacrifice" paddocks are located as far away as possible from watercourses and runoff is directed towards nutrient buffer zones.

\section{Beyond the Farmgate}

We believe the dairy industry must be committed to building relationships with the community. It is imperative the industry keep all parties talking from three levels of government to catchment management authorities, significant others and funding partners.

Successful businesses must be customer focused. As farmers rarely have direct contact with the end user of their products they intrinsically must use innovative and creative methods to successfully reach the consumer. Consumers place a lot of faith and their health in the hands of many along the food supply chain - farmers, processors, manufacturers, distributors and retailers. When 65\% (Landcare Survey 2006) of Australians have little knowledge of farmers and farming practices as an industry, we must make the most of every opportunity to reinforce to the consumer their continuing faith in our product is warranted. Consequently Clover Hill Dairies take every opportunity to promote the current developments in agriculture, communicate agriculture's relevance and champion its successes. Clover Hill Dairies promotional target demographic is the next generation of consumers and people who potentially would view dairying as a career of first choice. On a personal level, I am part of the Dairy Australia marketing initiative that provides "grass roots" dairy advocates with the necessary skills and resources to promote the industry in the best possible light to the 
wider community.

Desired outcomes from this bottom up approach include creating a favourable industry profile amongst key audiences and decision makers to:

- Attract labour to the industry.

- Attract investment capital to secure longer term growth.

- Positively influence government policies on the use of vital natural resources.

- Lift the level of morale within the industry and increase the capability and capacity of the industry to grow and develop further.

\section{Summation}

It's not all perfect and there is still a long way to go but we believe if you are persistent, back your own judgment, focus on the important things, surround yourself with people you can learn from and most importantly keep learning you will back a winner.

\section{Business philosophy}

To always dream and shoot higher than you know you can do. Don't bother just to be better than your contemporaries or predecessors. Try to be better than yourself. - WiLLIAM FAULKNER. 